\title{
New formulation and characterization of enhanced bulk-organic phase change materials
}

\author{
Anabel Palacios ${ }^{1,2}$, Alvaro de Gracia ${ }^{3}$, Luisa F. Cabeza ${ }^{1}$, Enrique Julià ${ }^{4}$, A. Inés \\ Fernández ${ }^{2}$, Camila Barreneche ${ }^{2,{ }^{*}}$ \\ ${ }^{1}$ GREA Innovació Concurrent, Universitat de Lleida, Edifici CREA, Pere de Cabrera s/n, 25001, Lleida. \\ 2 Department of Materials Science \& Physical Chemistry, Universitat de Barcelona, Martí i Franqués 1, \\ 08028, Barcelona. \\ ${ }^{3}$ Departament d'Enginyeria Mecanica, Universitat Rovira i Virgili, Av. Paisos Catalans 26, 43007 \\ Tarragona, Spain.
}
${ }^{4}$ Departamento de Ingenieria Mecanica y Construccion, Universitat Jaume I, 12071-Castellon de la Plana, Spain
*Corresponding author: c.barreneche@ub.edu

\begin{abstract}
The main drawbacks faced by researchers to successfully implement organic-PCM as materials to improve the thermal performance of building systems are their low thermal conductivity, their high flammability, and their low thermal cycling stability. $T$ In the present work, authors present a new enhanced PCM formulations aimed to solve the stated disadvantages in organic bulk-PCM. The new enhanced PCM were prepared by adding high thermal conductivity particles and two kinds of flame retardants into organic PCM (paraffin and fatty acid eutectic mixtures). In the first stage, the effective thermal conductivity of organic-PCM was increased by using two different methods: directly dispersion of powder graphite (PG) bulk-PCM and vacuum impregnation of PCM into expanded graphite (EG). In the second stage, the fire reaction behaviour of the thermal conductivity enhanced PCM formulations was improved by adding two kind of flame retardant: magnesium hydroxide and ammonium phosphate (APP).. Their fire reaction behaviour, thermal conductivity and thermophysical properties were measured by adapting the dripping test (UNE 23727-90), the hot-wire method and Differential Scanning Calorimetry (DSC), respectively. The enhanced PCM composites show a self-extinguished behaviour in terms of fire performance mechanism. The EG working with endothermic and phosphates flame retardants improve the fire performance of PCM by acting as a synergic system and the thermal conductivity is increased. However, their thermal storage capacity is significant decreased due to the large amount of flame retardant added (up to 40\%). The thermal reliability was also tested, the enhanced PCM composites were stable up to 1000 thermal cycles.
\end{abstract}

Keywords: Phase change materials (PCM), thermal energy storage (TES), thermal enhancement, graphite, flame retardants. 


\section{Introduction}

The concept of storing heat in the building walls as passive systems has been widely investigated for several applications as solar space heating systems [1], solar cooling [2], Trombe walls by using solar energy [3], and heating and cooling systems in buildings [4]. Thermal energy can be stored as latent heat (LHS) [5], sensible heat (SHS) [6], or thermochemical heat [7]. The number of articles concerning the PCM integration in building has increased during the last years [8]-[12]. PCM allows to store and release high quantities of heat per unit mass within a desired thermal gradient acting as a thermal regulator [9]. The effect of thermal energy storage in the building envelope is to reduce the indoor temperature fluctuations and to delay the air temperature extremum [9].

PCM are classified into organic and inorganic materials $[11,12]$. Both types of organic PCM present advantages and disadvantages which makes them suitable for a specific application. Regarding organic PCM, the main drawbacks are the low thermal conductivity and its high flammability [14] although organic PCM accomplishes large requirements to be used as latent heat material in the building envelope such as: low segregation, low corrosion issues, and long-term performance and stability [9]. The above stated disadvantages limit their implementation as LHS for passive systems in building walls/ceiling/floors.

Researchers put enormous efforts to successfully increase the thermal conductivity of organic PCM by adding high conductivity materials to improve the building comfort in building indoors [5]. The PCM doped with high conductivity particles has been developed in different ways as was reviewed by Jegadheeswarran and Pohekar [14] to enhance the thermal conductivity performance of PCM. The methods investigated, the references of those studies, and the conclusions extracted are described and summarized in Table 1. The highest improvement has been reported by the addition of high thermal conductivity particles such as different forms of graphite or nanoparticles [15]-[18].

Table 1. Methods managed by researchers to improve thermal conductivity of PCM

\begin{tabular}{|l|l|l|l|}
\hline Methods & Conductive particles & \multicolumn{1}{|c|}{ Conclusions } & Ref. \\
\hline $\begin{array}{l}\text { Impregnation of high } \\
\text { conductivity porous } \\
\text { material }\end{array}$ & $\begin{array}{l}\text { Metal matrixes and } \\
\text { expanded or flake graphite } \\
\text { matrix. }\end{array}$ & $\begin{array}{l}\text { The latent heat is reduced } \\
\text { by increasing mass fraction } \\
\text { of graphite. }\end{array}$ & {$\left[\begin{array}{l}{[1],[19]-} \\
{[24]}\end{array}\right.$} \\
\hline $\begin{array}{l}\text { Dispersion of high } \\
\text { conductivity particles }\end{array}$ & Metal particles and graphite. & $\begin{array}{l}\text { The porous size is a crucial } \\
\text { parameter. Metals not } \\
\text { compatible with all PCM. }\end{array}$ & [25]-[27] \\
\hline $\begin{array}{l}\text { Placing of metal } \\
\text { structures }\end{array}$ & $\begin{array}{l}\text { Different geometrical metal } \\
\text { structures. }\end{array}$ & $\begin{array}{l}\text { Not a promising solution } \\
\text { due to corrosion, less } \\
\text { publications on this topic. }\end{array}$ & [28], [29] \\
\hline $\begin{array}{l}\text { Use of high conductivity } \\
\text { and low density material }\end{array}$ & $\begin{array}{l}\text { Graphite, nanoparticles and } \\
\text { carbon nanotubes. }\end{array}$ & $\begin{array}{l}\text { The dispersion into PCM } \\
\text { matrix is an important } \\
\text { parameter. Huge increment } \\
\text { of thermal conductivity (up } \\
\text { to 700\%) and heat transfer. }\end{array}$ & [15]-[18] \\
\hline
\end{tabular}

Several studies have been also target to decrease the high flammability of organic PCM. It has been found that the flammability can be decreased by doping the material with flame retardants but not all flame retardants will work properly with all PCM available [30]. Therefore, a flame retardant selection must be performed previous to material preparation. The flame retardants types mainly managed by researchers are 
split into three mechanisms-systems and described in Table 2. Cai et al. [31] investigated the effect of adding expanded graphite (EG) and ammonium phosphate (APP) - char forming flame retardants - to PCM composites based on paraffin/HDPE. Palmitic acid/silicon dioxide $\left(\mathrm{SiO}_{2}\right)$ composites were studied by Fang et al. [32]. Palacios et al. [33] studied organic-bulk-PCM flammability and appraise that fatty acid in combination with endothermic decomposition flame retardants acted properly by decreasing their flammability while paraffin slightly decrease their flammability by adding char forming flame retardants (phosphates).

Table 2. Flame retardant mechanisms.

\begin{tabular}{|l|l|l|l|}
\hline Mechanisms & \multicolumn{1}{|c|}{ Mechanism action } & Flame retardant & Ref. \\
\hline $\begin{array}{l}\text { Gas phase flame } \\
\text { retardants }\end{array}$ & $\begin{array}{l}\text { The flame retardant interferes with the } \\
\text { free radical combustion reaction. }\end{array}$ & $\begin{array}{l}\text { Halogenated flame } \\
\text { retardants }\end{array}$ & $\begin{array}{l}\text { [30], [34], } \\
\text { [35] }\end{array}$ \\
\hline $\begin{array}{l}\text { Endothermic flame } \\
\text { retardants }\end{array}$ & $\begin{array}{l}\text { The flame retardant endothermic } \\
\text { decomposition in a specific } \\
\text { temperature range evolves non- } \\
\text { flammable gases such as water or } \\
\mathrm{CO}_{2} \text { that have a dilution effect. }\end{array}$ & $\begin{array}{l}\text { Metal hydroxides and salts } \\
\text { with endothermic } \\
\text { decompositions }\end{array}$ & [36]-[38] \\
\hline $\begin{array}{l}\text { Char forming flame } \\
\text { retardants }\end{array}$ & $\begin{array}{l}\text { The flame retardant forms a protective } \\
\text { layer on the flammable material which } \\
\text { hinders the heat and the oxygen } \\
\text { transfer. }\end{array}$ & $\begin{array}{l}\text { Polyphosphates } \\
\text { Intumescent flame retardants } \\
\text { (IFRs) composed by } \\
\text { ammonium polyphosphate, } \\
\text { pentaerythritol and melamine }\end{array}$ & [39]-[42] \\
\hline
\end{tabular}

The studies listed above were target to either increase the low thermal conductivity or reduce the high flammability of organic PCM. Based on the literature review, a lack of studies aimed to solve both disadvantages developing one only PCM formulation has been found. In this work, the authors are intended to target both flaws by adding flame retardants and high thermal conductivity particles to both kind of bulk-organic PCM (paraffin and eutectic fatty acid mixtures). The present study is partially based on the work carried out by Palacios et al. [33], the flame retardant screening and fire reaction results reported have been used to select the flame retardant type and percentages used to formulate the enhanced-PCM.

The main goal of this study is to develop an enhanced organic PCM with improved thermal conductivity and low flammability to be use for building application purposes. To achieve that goal the authors deeply analyse the thermal conductivity, latent heat, fire reaction behaviour and thermal stability of the enhanced-PCM. Moreover, the novel enhanced PCM formulations are compared to other existing materials in the literature, highlighting the main pros and cons of the enhanced-PCM proposed. According to their thermal properties and fire behaviour different building applications alternatives are provided.

\section{Materials}

\subsection{PCM}

The PCM selected are paraffin RT-21 and two fatty acids eutectic mixtures based on capric acid (CA), myristic acid (MA), and palmitic acid (PA). The PCM studied are applicable to improve thermal comfort in buildings as wall passive systems due to their temperature phase change range close to the indoor thermal comfort temperatures in buildings. Furthermore, the results obtained are easily extrapolated to other paraffin 
PCM and different fatty acid mixtures. The thermophysical properties of the organic PCM evaluated are summarized in

Table 3.

Table 3. Thermal properties of organic PCM

\begin{tabular}{|l|c|c|c|}
\hline \multicolumn{1}{|c|}{ Compound } & Nomenclature & $\begin{array}{c}\text { Melting temperature } \\
\text { (ㅇ) }\end{array}$ & $\begin{array}{c}\text { Heat of fusion } \\
\text { (kJ/kg) }\end{array}$ \\
\hline Paraffin RT-21 & RT-21 & $19-22[43]$ & $125[43]$ \\
\hline $73.5 \%$ Capric acid $+26.5 \%$ Myristic acid & CAMA & $24.1[11]$ & $152[11]$ \\
\hline $75.2 \%$ Capric acid $+24.8 \%$ Palmitic acid & CAPA & $22.1[11]$ & $153[11]$ \\
\hline
\end{tabular}

\subsection{Conductivity additives}

Graphite and carbon nanotubes are the most deeply investigated and the most promising solution to enhance thermal conductivity of PCM as is listed in Table 1. However, the mass fraction increase of graphite leads to a reduction of the latent heat of composites. Therefore, a compromise between thermal conductivity increase and heat storage capacity must be achieved depending on the application of the LTS system.

Moreover, graphite presents proper cost to be used as an additive. Table 4 summarizes the mainly studies performed with organic PCM, the graphite form used, the techniques used to characterize the composites and the extracted conclusions. Based on the literature, graphite is commonly added to shape stabilized PCM [44], [45] or it is used as holding matrix with impregnated PCM [19], [46].

The graphite forms selected in this study to increase thermal conductivity of organic$P C M$, were expanded graphite (EG) and powder graphite (PG). These high thermal conductivity particles were chosen based on three criteria: the promising results reported in the literature, their low price, the market coverage, and the fact that they can improve the PCM thermal conductivity by adding little amounts. Both graphite materials were purchased from SGL Group ${ }^{\circledR}$ (see Figure 1).
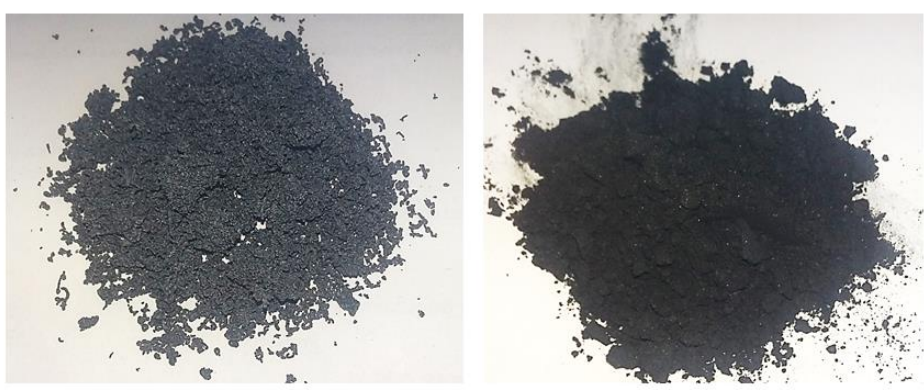

Figure 1. Expanded graphite - EG (left) and powder graphite - PG (right) 
Table 4. Methods managed by researchers to enhance thermal conductivity of PCM using graphite.

\begin{tabular}{|c|c|c|c|c|}
\hline PCM & Graphite form & Characterization & Conclusions & Ref. \\
\hline $\begin{array}{l}\text { Ternary eutectic mixture } \\
\text { of myristic acid (MA), } \\
\text { Palmitic acid (PA) and } \\
\text { Stearic acid (SA). }\end{array}$ & $\begin{array}{l}\text { Expanded graphite } \\
(E G)\end{array}$ & $\begin{array}{l}\text { Hot disk, differential scanning } \\
\text { calorimetry DSC, TGA, SEM, } \\
\text { Infrared spectroscopy FT-IR, } \\
\text { thermal cycling test. }\end{array}$ & $\begin{array}{l}\text { Optimum mass percentage: } 7.14 \% \text { Thermal conductivity improvement: } 900 \% \\
\text { Thermal cycles: good thermal stability after } 1000 \text { cycles. } \\
\text { Others: The latent heat and melting temperature is reduced by } 1.4 \% \text {. }\end{array}$ & [47] \\
\hline $\begin{array}{l}\text { Capric acid (CA), myristic } \\
\text { acid (MA) and palmitic } \\
\text { acid (PA) eutectic } \\
\text { mixtures }\end{array}$ & Expanded graphite. & $\begin{array}{l}\text { Hot disk, DSC, SEM, FT-IR, thermal } \\
\text { cycling test. }\end{array}$ & $\begin{array}{l}\text { Optimum mass percentage : } 7.14 \% \mathrm{EG} \\
\text { Thermal conductivity improvement: } 715 \% \\
\text { Thermal cycles: good thermal stability after } 1200 \text { cycles. } \\
\text { Others: the thermal storage and release rates were significantly increased. }\end{array}$ & {$[46]$} \\
\hline $\begin{array}{l}\text { Lauric acid (LA), myristic } \\
\text { acid (MA) and palmitic } \\
\text { acid (PA) ternary eutectic } \\
\text { mixtures }\end{array}$ & Expanded graphite. & $\begin{array}{l}\text { Plate heat flow meter method, SEM, } \\
\text { FT-IR, DSC. }\end{array}$ & $\begin{array}{l}\text { Optimum mass percentage: } 13.5 \% \mathrm{EG} \\
\text { Thermal conductivity improvement: } 695 \% \\
\text { Thermal cycles: good thermal reliability after } 50 \text { cycles } \\
\text { Others: the latent heat of composite were reduced by } 7 \% \text {. }\end{array}$ & {$[48]$} \\
\hline $\begin{array}{l}\text { Paraffin } \\
\text { (n-docosane) }\end{array}$ & $\begin{array}{l}\text { Expanded natural } \\
\text { graphite. }\end{array}$ & Hot-wire method, DSC. & $\begin{array}{l}\text { Optimum mass percentage: } 10 \% \mathrm{EG} \\
\text { Thermal conductivity improvement: } 272 \% \text { (from } 0.22 \text { to } 0.82 \mathrm{~W} / \mathrm{m} \mathrm{K} \text { ) } \\
\text { Thermal cycles: none } \\
\text { Others: The latent heat capacity of the composite was reduced by } 8.4 \% \text {. }\end{array}$ & [49] \\
\hline Technical grade paraffin & Expanded graphite. & $\begin{array}{l}\text { Transient plane Heat source } \\
\text { technique, polarizing optical } \\
\text { microscope (POM), DSC, density } \\
\text { and porosity. }\end{array}$ & $\begin{array}{l}\text { Optimum mass percentage: } 10 \% \text { EG } \\
\text { Thermal conductivity improvement: } 1150 \% \text { (from } 0.305 \text { to } 3.525 \mathrm{~W} / \mathrm{m} \mathrm{K} \text { ) } \\
\text { Thermal cycles: none } \\
\text { Others: the heat storage/retrieval durations for EG (10)/paraffin (90) composite } \\
\text { were reduced by } 48.9 \% \text { and } 66.5 \% \text {, respectively, compared to pure paraffin }\end{array}$ & {$[50]$} \\
\hline Paraffin & $\begin{array}{l}\text { Graphite powder (GP) } \\
\text { and EG }\end{array}$ & Hot disk, SEM, DSC, FT-IR. & $\begin{array}{l}\text { Optimum mass percentage: } 4.6 \% \text { EG and } 16 \% \text { GP } \\
\text { Thermal conductivity improvement: } 339 \% \text { for } E G \text { and } 68 \% \text { for GP. } \\
\text { Thermal cycles: none } \\
\text { Others: the latent heat is decreased by } 1-2 \% \text {. }\end{array}$ & {$[51]$} \\
\hline Paraffin & Nano-graphite (NG) & $\begin{array}{l}\text { Hot disc, environmental scanning } \\
\text { electron microscope (ESEM), DSC. }\end{array}$ & $\begin{array}{l}\text { Optimum mass percentage: } 10 \% \text { NG } \\
\text { Thermal conductivity improvement: } 641 \% \\
\text { Thermal cycles: good thermal reliability after } 1000 \text { cycles. } \\
\text { Others: the latent heat and phase change temperature decreased with an } \\
\text { increase of the mass fraction of graphite by } 13 \% \text {. }\end{array}$ & [52] \\
\hline Octadecanoic acid & Graphene aerogel (GA) & $\begin{array}{lrr}\text { Laser flash } & \text { analyser }(\text { LFA), } & \text { Field } \\
\text { Emission } & \text { Scanning } & \text { Electron } \\
\text { Microscopy } & \text { (FESEM), } & \text { X-Ray } \\
\text { diffraction (XRD), DSC. } & \end{array}$ & $\begin{array}{l}\text { Optimum mass percentage: } 20 \% \text { (GA) } \\
\text { Thermal conductivity improvement: } 1331 \% \\
\text { Thermal cycles: none } \\
\text { Others: the latent heat of the composite was very close to the value of the } \\
\text { octadecaoinc acid, only varying a } 2 \% \text {. }\end{array}$ & [53] \\
\hline
\end{tabular}




\subsection{Flame retardants}

Based on the work reported by Palacios et al. [33], two different flame retardants were used to perform this study: an endothermic flame retardant (commercial grade of magnesium hydroxide) for fatty acids and a commercial char forming flame retardant for paraffin RT-21 (ammonium polyphosphate (APP)) [30]. The onset decomposition temperature and enthalpy of decomposition of flame retardants used selected are summarized in Table 5.

Table 5. Properties of flame retardants used [33]

\begin{tabular}{|c|c|c|c|}
\hline Compound & Method & $\begin{array}{c}\text { Onset decomposition } \\
\text { temperature (ㅇ) }\end{array}$ & $\begin{array}{c}\text { Enthalpy of decomposition } \\
\text { (kJ/kg) }\end{array}$ \\
\hline $\begin{array}{c}\text { Magnesium } \\
\text { hydroxide }\end{array}$ & $\begin{array}{c}\text { Endothermic } \\
\text { decomposition }\end{array}$ & 340 & 1450 \\
\hline APP & Char forming & 190 & - \\
\hline
\end{tabular}

\section{Experimental procedure}

3.1 PCM- graphite composite preparation

The PCM/graphite composite have been prepared following two different methods depending on the graphite form used:

- PCM/EG composite: The organic PCM were impregnated into EG by the vacuum impregnation method. The EG was added to melted PCM located in a reactor at $70 \stackrel{\circ}{\circ}$. The selected temperature was chosen to cover the PCM melting point and to guarantee the proper PCM fusion. The temperature and the vacuum condition were maintained constant during one hour to allow the PCM to impregnate the EG porous. After one hour, the PCM/EG composite was kept into a vessel at room conditions. Two different concentrations of $E G$ were studied: $0.5 \%$ wt. and $1 \%$ wt. Those percentages were selected to ensure the minimal disturbance in phase change enthalpy and melting temperature whereas the effective thermal conductivity of PCM is increased in such significant percentage [46]-[48].

- PCM/Powder graphite: The powder graphite was directly dispersed into the melted PCM. During the dispersion process, the mixture was vigorously mixed to achieve a proper and homogeneous dispersion of the particles into the melted PCM. The powder graphite percentages added in this case were $1 \%$ wt. and $2 \%$ wt. The addition of a higher percentage than $2 \%$ would have led to a decrease and disruption in the heat transfer capacity of the PCM. Furthermore, supernatant graphite was observed in previous lab tests dispersing a higher percentage of graphite in PCM.

\subsection{PCM-graphite composite characterization}

\subsubsection{Effective thermal conductivity}

The effective thermal conductivity was evaluated using a hot-wire KD2 Pro thermal analyser device. The hot wire works by the transient line heat source method [54] to 
measure effective thermal conductivity, resistivity, diffusivity, and specific heat. The KS1 was the sensor used to test the samples, $1.27 \mathrm{~mm}$ diameter $\times 6 \mathrm{~cm}$ long. The equipment accuracy is $\pm 5 \%$ in the range of 0.2 to $2 \mathrm{~W} / \mathrm{m} \cdot \mathrm{K}$ and $\pm 0.01 \mathrm{~W} / \mathrm{m} \cdot \mathrm{K}$ in the range of 0.02 to $0.2 \mathrm{~W} / \mathrm{m} \cdot \mathrm{K}$.

The measurements were performed by placing the PCM/graphite composites into a vessel $(2 \mathrm{~cm} \times 6 \mathrm{~cm})$. The sensor was introduced through a hole into the vessel lid. Note that the effective thermal conductivity was measured in the axial direction because is the direction where the graphite presents higher thermal conductivity due to its anisotropic behaviour. For statistical studies, each sample was tested 6 times to attain an accurate scattered of conductivity heat results under steady state conditions.

\subsubsection{Thermophysical properties}

The melting temperature and heat storage capacity behaviour of PCM/graphite formulations were studied using a DSC 822e device supplied by Mettler Toledo. The data were collected with a $50 \mathrm{ml} / \mathrm{min} \mathrm{N}_{2}$ flow over a temperature range between $T_{\text {melting }}$ $\pm 10^{\circ} \mathrm{C}$. The measurements were performed using around $15 \mathrm{mg}$ sample, located into $40 \mu \mathrm{L}$ aluminium crucibles, and $0.5 \mathrm{~K} / \mathrm{min}$ temperature rate as recommended in previous studies [55]. The equipment precision is $\pm 0.1^{\circ} \mathrm{C}$ for temperature and $\pm 1 \mathrm{~kJ} / \mathrm{kg}$ for enthalpy results.

\subsubsection{Thermal reliability}

The PCM-composites that show better performance were tested to determine the thermal cycling stability after 1000 thermal cycles. Thermal cycles were programmed in a thermal cycler Bioer Gene Q T-18 which allows a tub volume of $0.5 \mathrm{ml}$; and a dynamic method was established following a temperature range between $15 \stackrel{\circ}{\circ}$ and 35 ${ }^{\circ} \mathrm{C}$ and a $0.2 \mathrm{~K} / \mathrm{min}$ heating rate. The thermal stability after 1000 thermal cycles was evaluated by Fourier Transformed Infrared (FT-IR) spectroscopy. The FT-IR experiments were conducted through FT-IR Spectrum Two ${ }^{\mathrm{TM}}$ from Perkin Elmer supported by Dynascan ${ }^{\mathrm{TM}}$ interferometer and OpticsGuard ${ }^{\mathrm{TM}}$ using a working range from $400 \mathrm{~cm}^{-1}$ to $4000 \mathrm{~cm}^{-1}$ and coupled with attenuated total reflectance (ATR) accessory.

Ferrer et al. [56] concluded that the chemical structure of a material is stable over thermal cycles, the thermophysical properties will be also stable. According to that statement, the latent heat and melting temperature of the thermal cycled formulations was not studied.

\subsection{Enhanced PCM characterization}

An enhanced PCM formulation was prepared to increase thermal conductivity and reduce the flammability of $\mathrm{PCM}$, both at the same time. The formulation with the best thermal performance were used to prepare the enhanced PCM by adding the proper flame retardant for each PCM as stated by Palacios et al. [33]. The vacuum impregnation was conducted by introducing in the reactor at the same time the flame retardant and graphite by following the same procedure described above for PCM/EG composites.

The flammability behaviour of enhanced PCM (PCM/graphite/flame retardant composite) was characterized by the dripping test. The device is described in the 
Spanish standard UNE 23727-90 and the tests were adapted to such standard. The procedure followed to characterize the fire reaction was as follows: the samples were weighted and introduced into a ceramic crucible, which was placed on a metallic grid 3 $\mathrm{cm}$ below the heat source $(500 \mathrm{~W})$, during the first 5 minutes of combustion the heat source was taken away and put back after each ignition and extinction process. Three samples of each formulation were tested and the parameters determined were the time to ignition, the number of ignitions and the average time of flame persistence. The equipment used to perform the dripping test is shown in Figure 2.
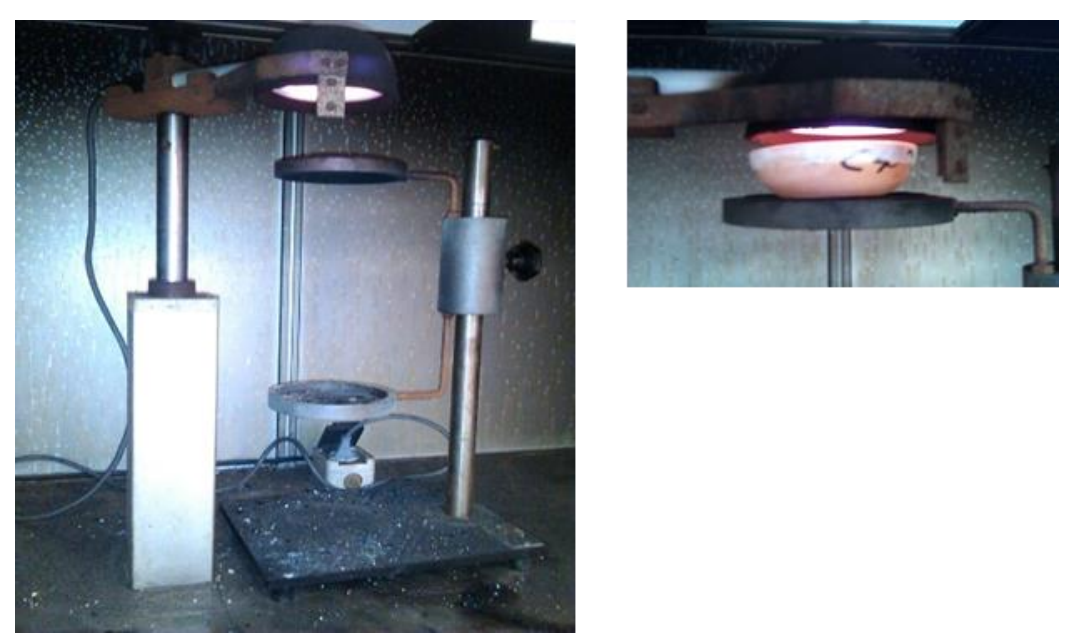

Figure 2. Dripping test equipment used to perform the fire reaction test of PCMcomposites

Based on the previous study conducted by Palacios et al. [41] sample formulations characterized under dripping test are shown in Table 6.

Table 6. Sample formulations under fire-reaction dripping test

\begin{tabular}{|l|l|}
\hline Formulations & Nomenclature \\
\hline Paraffin RT-21+1\% EG + 40\% APP & RT-21/EG/APP \\
\hline $\mathrm{CA}+\mathrm{MA}+1 \% \mathrm{EG}+50 \%$ Magnesium hydroxide & $\mathrm{CAMA} / \mathrm{EG} / \mathrm{MH}$ \\
\hline $\mathrm{CA}+\mathrm{PA}+1 \% \mathrm{EG}+50 \%$ Magnesium hydroxide & $\mathrm{CAPA} / \mathrm{EG} / \mathrm{MH}$ \\
\hline
\end{tabular}

Therefore, as three different PCM have been selected, three different samples containing the best graphite amount and type in combination with the proper fire retardant were tested under dripping test. In addition, the samples listed in the Table 6 were analysed by DSC, Hot wire (KD2 Pro) and thermal cycled following the same specifications exposed above for PCM-graphite characterization.

\section{Results and discussion}

\subsection{PCM-graphite composites}

\subsubsection{Thermal properties}


The effective thermal conductivity for each measurement, the mean thermal conductivity and the thermal conductivity enhancement for each PCM and conductivity particle formulation are shown in Table 7. The thermal conductivity of the pure PCM was also measured in liquid and solid state (liquid/solid): the thermal conductivity of paraffin was $0.154 / 0.224 \mathrm{~W} / \mathrm{m} \cdot \mathrm{K}$, for $\mathrm{CA}+\mathrm{MA}$ was $0.172 / 0.150 \mathrm{~W} / \mathrm{m} \cdot \mathrm{K}$ and for CA+PA was $0.161 / 0.254 \mathrm{~W} / \mathrm{m} \cdot \mathrm{K}$.

The formulations that shows the best thermal performance (high thermal conductivity) for each PCM are those highlighted in bold (see Table 7), which are the ones containing $\mathrm{PCM}+1 \% \mathrm{EG}$. The method that provides the highest thermal conductivity enhancement is the impregnation of $1 \% E G$, with an increase of $255 \%$ for the $\mathrm{CA}+\mathrm{PA}+1 \% \mathrm{EG}$ composite. The paraffin-graphite composites $+1 \% \mathrm{EG}$ and $\mathrm{CA}+\mathrm{MA}+$ $1 \%$ EG show $134 \%$ and $148 \%$ thermal conductivity increment, respectively. These results are in good agreement with the literature data (see Table 4), the addition of expanded graphite increases the thermal conductivity in a larger extent than powder graphite [51]. Comparing the thermal conductivity enhancement percentages, according to [50] the impregnation of $10 \%$ EG into paraffin lead to an increase of $1150 \%$ while we obtained a $134 \%$ increment by impregnating $1 \% \mathrm{EG}$. In case of fatty acid mixtures, an enhancement of $900-700 \%$ was found in the literature by impregnating $7 \%$ EG [48] while we enhanced the thermal conductivity by $150-250 \%$ by impregnating $1 \% \mathrm{EG}$.

The thermal conductivity was improved in all the cases except for the formulation of $\mathrm{CA}+\mathrm{PA}+1 \% \mathrm{PG}$, where the addition of graphite does not seem to affect the thermal conductivity value. For such formulation, the proper graphite dispersion might be unreachable, and the thermal conductivity effect was negligible.

Table 7. Results obtained by effective thermal conductivity test

\begin{tabular}{|c|c|c|c|c|c|}
\hline & Samples & $\begin{array}{c}\text { Effective } \\
\text { thermal } \\
\text { conductivity } \\
(\mathrm{W} /(\mathrm{m} \cdot \mathrm{K}))\end{array}$ & Error & $\begin{array}{c}\text { Mean effective } \\
\text { thermal } \\
\text { conductivity } \\
(\mathrm{W} /(\mathrm{m} \cdot \mathrm{K}))\end{array}$ & $\begin{array}{c}\text { Thermal } \\
\text { conductivity } \\
\text { enhancement }\end{array}$ \\
\hline \multirow{20}{*}{ 轧紊 } & \multirow{6}{*}{ Paraffin RT-21 + 1\% PG } & 0.272 & 0.0452 & \multirow{6}{*}{$0.21 \pm 0.04$} & \multirow{6}{*}{$39 \%$} \\
\hline & & 0.206 & 0.0511 & & \\
\hline & & 0.255 & 0.0250 & & \\
\hline & & 0.185 & 0.0089 & & \\
\hline & & 0.192 & 0.0172 & & \\
\hline & & 0.181 & 0.0128 & & \\
\hline & \multirow{6}{*}{ Paraffin RT-21 + 2\% PG } & 0.271 & 0.0776 & \multirow{6}{*}{$0.17 \pm 0.05$} & \multirow{6}{*}{$9 \%$} \\
\hline & & 0.136 & 0.0061 & & \\
\hline & & 0.130 & 0.0150 & & \\
\hline & & 0.151 & 0.0027 & & \\
\hline & & 0.160 & 0.0078 & & \\
\hline & & 0.161 & 0.0041 & & \\
\hline & \multirow{6}{*}{ Paraffin RT-21 + 0.5\% EG } & 0.166 & 0.0089 & \multirow{6}{*}{$0.18 \pm 0.02$} & \multirow{6}{*}{$15 \%$} \\
\hline & & 0.177 & 0.0115 & & \\
\hline & & 0.186 & 0.0148 & & \\
\hline & & 0.181 & 0.0085 & & \\
\hline & & 0.210 & 0.0198 & & \\
\hline & & 0.144 & 0.0073 & & \\
\hline & \multirow{2}{*}{ Paraffin RT-21 + 1\% EG } & 0.346 & 0.0024 & \multirow{2}{*}{$0.36 \pm 0.01$} & \multirow{2}{*}{$134 \%$} \\
\hline & & 0.368 & 0.0044 & & \\
\hline
\end{tabular}




\begin{tabular}{|c|c|c|c|c|c|}
\hline & & 0.371 & 0.0045 & & \\
\hline & & 0.373 & 0.0047 & & \\
\hline & & 0.354 & 0.0063 & & \\
\hline & & 0.357 & 0.0061 & & \\
\hline \multirow{24}{*}{ 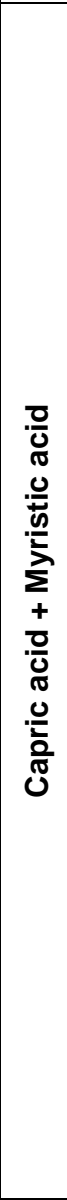 } & \multirow{6}{*}{$C A+M A+1 \% P G$} & 0.165 & 0.0087 & \multirow{6}{*}{$0.16 \pm 0.001$} & \multirow{6}{*}{$2 \%$} \\
\hline & & 0.166 & 0.0053 & & \\
\hline & & 0.162 & 0.0062 & & \\
\hline & & 0.164 & 0.0031 & & \\
\hline & & 0.163 & 0.0023 & & \\
\hline & & 0.162 & 0.0037 & & \\
\hline & \multirow{6}{*}{$C A+M A+2 \% P G$} & 0.171 & 0.0062 & \multirow{6}{*}{$0.17 \pm 0.004$} & \multirow{6}{*}{$5 \%$} \\
\hline & & 0.165 & 0.0067 & & \\
\hline & & 0.172 & 0.0087 & & \\
\hline & & 0.167 & 0.0066 & & \\
\hline & & 0.173 & 0.0055 & & \\
\hline & & 0.161 & 0.0042 & & \\
\hline & \multirow{6}{*}{$C A+M A+0.5 \% E G$} & 0.198 & 0.0167 & \multirow{6}{*}{$0.20 \pm 0.004$} & \multirow{6}{*}{$24 \%$} \\
\hline & & 0.200 & 0.0228 & & \\
\hline & & 0.206 & 0.0272 & & \\
\hline & & 0.191 & 0.0264 & & \\
\hline & & 0.198 & 0.0282 & & \\
\hline & & 0.201 & 0.0298 & & \\
\hline & \multirow{6}{*}{$C A+M A+1 \% E G$} & 0.628 & 0.0036 & \multirow{6}{*}{$0.63 \pm 0.02$} & \multirow{6}{*}{$148 \%$} \\
\hline & & 0.658 & 0.0047 & & \\
\hline & & 0.628 & 0.0069 & & \\
\hline & & 0.628 & 0.0047 & & \\
\hline & & 0.608 & 0.0034 & & \\
\hline & & 0.628 & 0.0023 & & \\
\hline \multirow{21}{*}{ 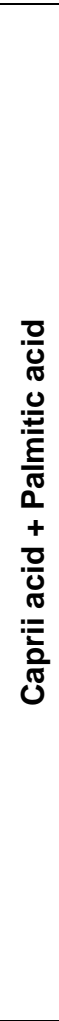 } & \multirow{6}{*}{$C A+P A+1 \% P G$} & 0.173 & 0.0027 & \multirow{6}{*}{$0.17 \pm 0.01$} & \multirow{6}{*}{$0 \%$} \\
\hline & & 0.171 & 0.0014 & & \\
\hline & & 0.172 & 0.0034 & & \\
\hline & & 0.174 & 0.0023 & & \\
\hline & & 0.171 & 0.003 & & \\
\hline & & 0.171 & 0.0028 & & \\
\hline & \multirow{6}{*}{$C A+P A+2 \% P G$} & 0.276 & 0.0749 & \multirow{6}{*}{$0.18 \pm 0.05$} & \multirow{6}{*}{$3 \%$} \\
\hline & & 0.144 & 0.0042 & & \\
\hline & & 0.150 & 0.0068 & & \\
\hline & & 0.143 & 0.0055 & & \\
\hline & & 0.164 & 0.0021 & & \\
\hline & & 0.183 & 0.0064 & & \\
\hline & \multirow{6}{*}{$C A+P A+0.5 \% E G$} & 0.292 & 0.0054 & & \\
\hline & & 0.277 & 0.0179 & & \\
\hline & & 0.246 & 0.0092 & & \\
\hline & & 0.242 & 0.007 & $0.26 \pm 0.02$ & $51 \%$ \\
\hline & & 0.243 & 0.0073 & & \\
\hline & & 0.294 & 0.0053 & & \\
\hline & & 0.519 & 0.0039 & & \\
\hline & $C A+P A+1 \% E G$ & 0.545 & 0.0074 & $0.53 \pm 0.01$ & $256 \%$ \\
\hline & & 0.548 & 0.0096 & & \\
\hline
\end{tabular}




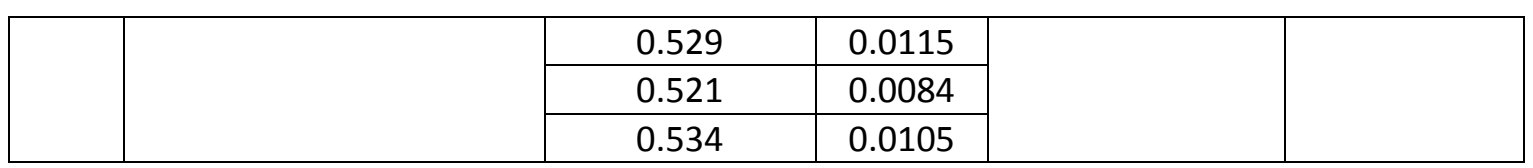

DSC results for the best thermal performance of PCM/graphite composites (composite containing $1 \%$ of $E G$ ) are listed in Table 8 . The graphite does not lead to a melting temperature and latent heat reduction higher than $3^{\circ} \mathrm{C}$ and $18 \mathrm{~kJ} / \mathrm{kg}$ since the amount of graphite additives used in this study on purpose is minimum (less than $2 \% \mathrm{wt}$.). Thereby, the melting enthalpy is reduced by $11 \%$ and $8 \%$ for the studied CAMA/EG and CAPA/EG samples due to the mixtures law [58]. In the case of paraffin, the melting enthalpy is also slightly decreased due to the EG addition, by $10 \%$. The melting temperatures remain almost constant for RT-21 and CAPA samples, varying a $1 \%$ and $3 \%$, respectively. Otherwise, the melting temperature of CAPA/EG is slightly increased attributed to systematic equipment error of the measurements.

Table 8. DSC results for the optimum formulations of thermal conductivity enhancement

\begin{tabular}{|c|c|c|c|c|}
\hline Formulations & $\begin{array}{c}\text { Melting } \\
\text { temperature (으) }\end{array}$ & $\begin{array}{c}\text { Modification } \\
(\mathbf{o} \mathbf{C})\end{array}$ & $\begin{array}{c}\text { Fusion enthalpy } \\
\mathbf{( k J / k g )}\end{array}$ & $\begin{array}{c}\text { Modification } \\
(\mathbf{k J} / \mathbf{k g})\end{array}$ \\
\hline Paraffin RT-21+1\% EG & $20.3 \pm 0.1$ & $-0.7(3 \%)$ & $112 \pm 2$ & $-13(10 \%)$ \\
\hline $\mathrm{CA}+\mathrm{MA}+1 \% \mathrm{EG}$ & $21.7 \pm 0.1$ & $-2.4(9 \%)$ & $134 \pm 2$ & $-18(11 \%)$ \\
\hline $\mathrm{CA}+\mathrm{PA}+1 \% \mathrm{EG}$ & $22.4 \pm 0.1$ & $+0.3(1 \%)$ & $140 \pm 2$ & $-13(8 \%)$ \\
\hline
\end{tabular}

\subsubsection{Thermal reliability}

The thermal cycling stability has been evaluated by differences between FT-IR spectra before and after 1000 thermal cycles for thermal conductivity enhanced formulations. FT-IR characteristic peaks of paraffin RT-21 are at $2853 \mathrm{~cm}^{-1}$ and $2921 \mathrm{~cm}^{-1}$ corresponding to $\mathrm{CH}_{3}$ stretching. These characteristics peaks appear in the RT-21$1 \%$ wt. EG FT-IR spectra in a similar intensity before and after thermal cycling process as is shown in Figure 4a. Therefore, it can be concluded that there is not thermal degradation after 1000 thermal cycles.

Similarly, the studied fatty acid eutectic composites showed the same pattern. The distinctive bands are the alkane groups (2800-2950 $\left.\mathrm{cm}^{-1}\right)$ and carboxyl group (1714 $\left.\mathrm{cm}^{-1}\right)$. The FT-IR spectra of both eutectic fatty acids are shown in Figure $4 \mathrm{~b}$ and Figure $4 c$, respectively.

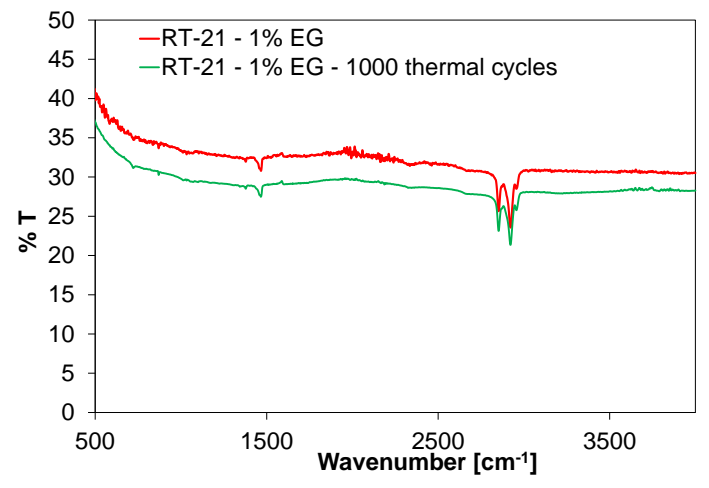


a)

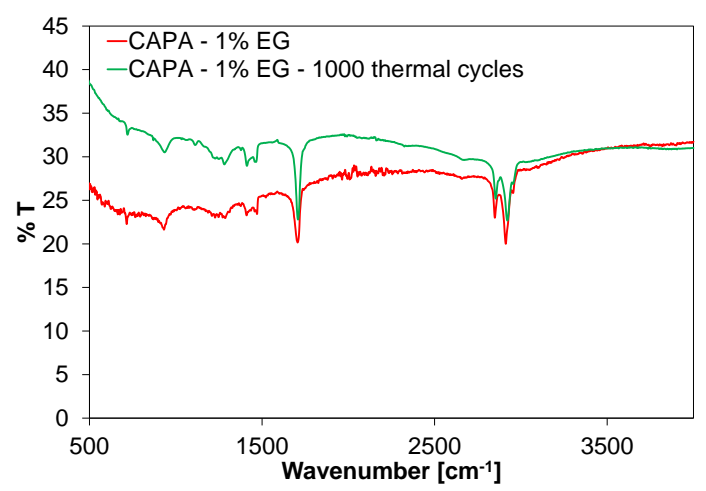

b)

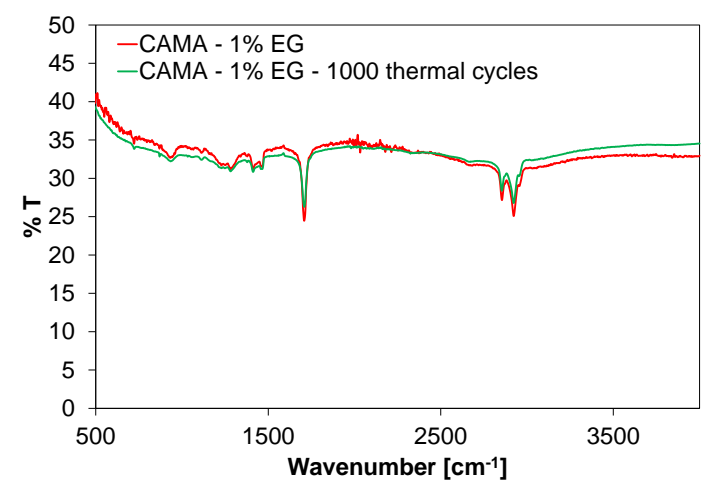

c)

Figure 3. FTIR spectra of Optimum PCM+EG formulations

Therefore, non-chemical degradation is observed in PCM/EG composites after 1000 thermal cycles (see Figure 4). Notice that the characteristic peaks of EG are not appreciable due to the low percentage of EG incorporated to the samples and if the chemical structure is stable, the thermophysical properties as phase change enthalpy and phase change temperature also remain constant.

\subsection{Enhanced PCM}

\subsubsection{Fire performance}

The fire reaction behaviour was considerably improved by adding EG to the formulations studied by Palacios et al. [41] where the fire reaction was evaluated by comparing PCM and PCM-flame retardant formulations.

The enhanced fatty acid PCM do not ignite more than 5 seconds during the test and the flame was quenched when the heat source was removed, showing a clear selfextinguished mechanism. A larger number of ignitions (more than 20) and shorter combustion time (4-5 seconds) was accounted.

In the case of paraffin enhanced PCM formulation, the combustion time was considerably reduced (from 300 to 21 seconds) and the number of ignitions accounted (9 ignitions) was the desired to perform a self-extinguished behaviour. Therefore, taking into account the results obtained in previous studies $[41,59]$ the EG contributes to improve fire mechanism performance acting as synergic agent with APP. The EG used for increase the thermal conductivity also helps in protecting the char layer and hence results in better thermal stability for PCM with flame retardants.

Table 9. Dripping test results for the enhanced PCM.

\begin{tabular}{|c|c|c|c|c|}
\hline $\begin{array}{c}\text { Flame retardant } \\
\text { (\%wt.) }\end{array}$ & Nomenclature & $\begin{array}{c}\text { Ignition time } \\
\mathbf{( s )}\end{array}$ & № of ignitions & $\begin{array}{c}\text { Combustion time } \\
\text { (s) }\end{array}$ \\
\hline Paraffin RT-21 & RT-21 & 26 & 1 & 300 \\
\hline $\begin{array}{c}60 \% \text { Paraffin + } \% \text { EG }+ \\
40 \% \text { APP }\end{array}$ & RT-21/EG/APP & 25 & 9 & 21 \\
\hline CA + MA & CAMA & 19 & 1 & 200 \\
\hline $50 \%(C A+M A)+1 \% E G+$ & CAMA/EG/MH & 22 & 21 & 4 \\
\hline
\end{tabular}




\begin{tabular}{|c|c|c|c|c|}
\hline $50 \% \mathrm{Mg}(\mathrm{OH})_{2}$ & & & & \\
\hline $\mathrm{CA}+\mathrm{PA}$ & $\mathrm{CAPA}$ & 12 & 1 & 224 \\
\hline $\begin{array}{c}50 \%(\mathrm{CA}+\mathrm{PA})+1 \% \mathrm{EG}+ \\
50 \% \mathrm{Mg}(\mathrm{OH})_{2}\end{array}$ & $\mathrm{CAPA} / \mathrm{EG} / \mathrm{MH}$ & 25 & 27 & 5 \\
\hline
\end{tabular}

\subsubsection{Thermal properties}

The conductivity enhancement percentage obatined for fatty acid/EG/MH was $144 \%$ and $91 \%$, respectively. Nevertheless, comparing the improvement shown to fatty acid/EG, almost $43 \%$ is reduced for capric acid and palmitic acid (255\% to $144 \%)$ and in case of capric acid and myristic acid eutectic mixture the thermal conductivity enhancement is reduced by $39 \%$ ( $149 \%$ to $91 \%$ ). Moreover, paraffin RT-21/EG/MH shows a thermal conductivity enhancement of $71 \%$, which is $47 \%$ lower than the percentage accounted for RT-21/EG (134\%). Note that this effect is caused by the addition of flame retardant, which behaves as non-conductive impurity particles.

The fusion enthalpy and melting temperature of formulations regarding enhanced PCM are listed in Table 10. The PCM/EG/Flame retardant melting temperature values does not differ much from the PCM/EG melting enthalpy values. Concerning fatty acids formulations, the fusion enthalpy obtained is $50 \%$ reduced in comparison to PCM/EG since the amount of magnesium hydroxide added is considerably higher. Therefore, the material is doped as $50 \%$ of a non-conductive additive. Moreover, the melting enthalpy of paraffin is $26 \%$ decreased attributed to the addition of $40 \%$ of APP.

Table 10. DSC and thermal conductivity results for the enhanced PCM.

\begin{tabular}{|c|c|c|c|}
\hline Samples (\%wt.) & $\begin{array}{c}\text { Melting } \\
\text { temperature } \\
(\mathbf{o} \mathbf{C})\end{array}$ & $\begin{array}{c}\text { Thermal } \\
\text { Latent heat } \\
(\mathbf{k J} / \mathbf{k g})\end{array}$ & $\begin{array}{c}\text { conductivity } \\
\text { enhancement } \\
(\mathbf{W} / \mathbf{m} \cdot \mathbf{K})\end{array}$ \\
\hline $\begin{array}{c}\text { Paraffin RT-21+ 1\% EG }+40 \% \\
\text { APP }\end{array}$ & 20.2 & 83 & $0.41(144 \%)$ \\
\hline $\begin{array}{c}(\mathrm{CA}+\mathrm{MA})+1 \% \mathrm{EG}+50 \% \\
\text { Magnesium hydroxide }\end{array}$ & 21 & 64 & $0.32(91 \%)$ \\
\hline $\begin{array}{c}(\mathrm{CA}+\mathrm{PA})+1 \% \mathrm{EG}+50 \% \\
\text { Magnesium hydroxide }\end{array}$ & 23 & 57 & $0.26(71 \%)$ \\
\hline
\end{tabular}

\subsubsection{Thermal reliability}

The thermal cycling stability was evaluated by following the same procedure, thermal cycles and techniques exposed for PCM/graphite composites. The FT-IR characteristic peaks of paraffin and fatty acids shown in the thermal stability previously analysed also appear in enhanced PCM FT-IR spectra (see Figure 5). Thereby, non-chemical degradation is observed due to the addition of flame retardant to PCM-graphite composite after 1000 thermal cycles. Therefore, as stated by Ferrer et al. [59] the thermal cycling stability is ensured. 

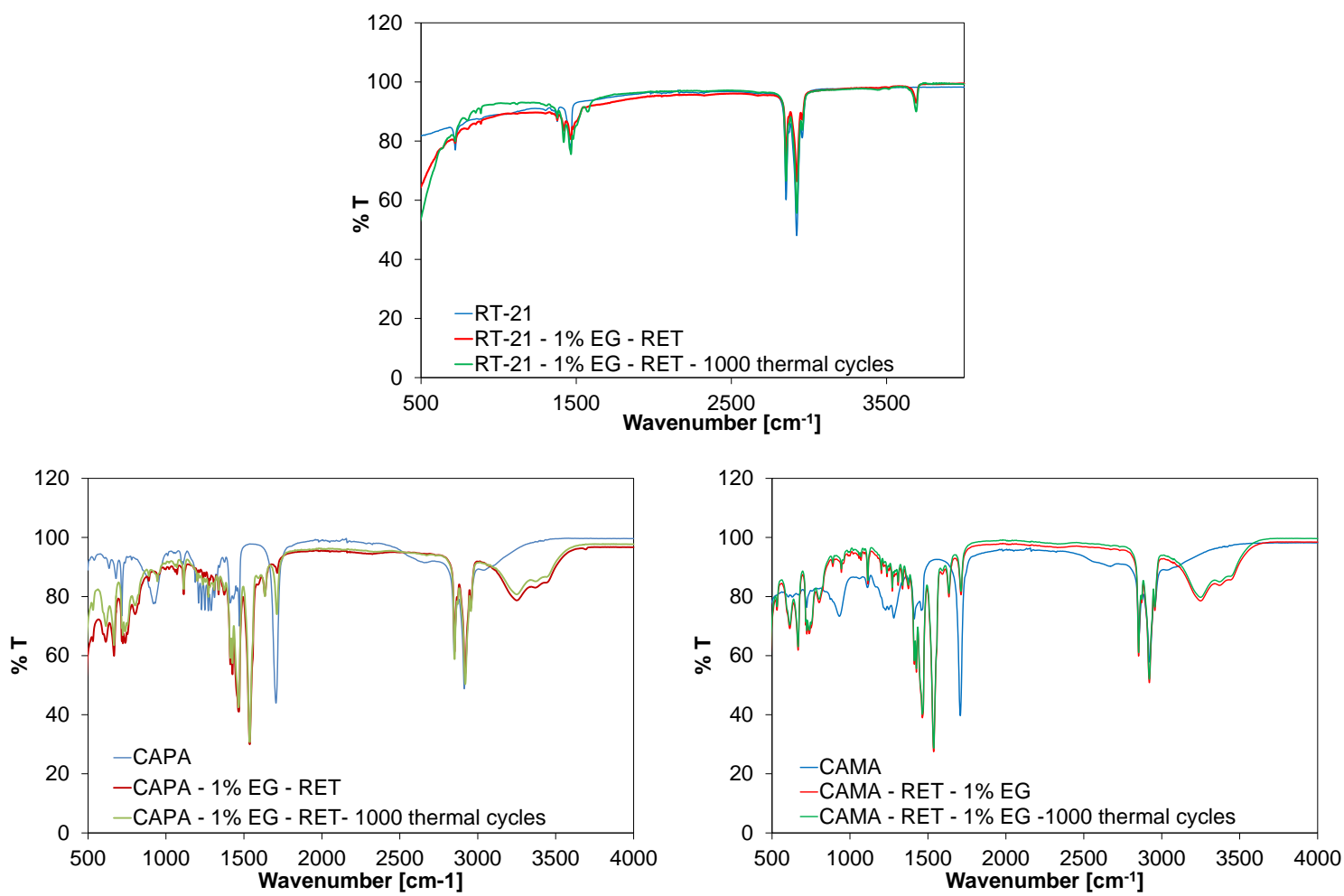

Figure 4. FTIR spectra of enhanced PCM formulations.

\section{Enhanced-PCM potential building applications.}

In this section the composites proposed are compared to other PCM composites based on building application materials in literature (see Table 11). Few papers found in literature are aimed to increase the thermal conductivity and the fire reaction behaviour at the same time by means of developing one shape stabilized composite [31,57]. In such investigations, paraffin was selected as the base PCM and the EG was used as a synergic agent, so the thermal conductivity enhancement was not actually measured. The fire reaction was tested using a cone calorimeter which allows to measure the heat released under pyrolysis conditions and analysing the chart resulted from the combustion. The authors concluded that the flammability was improved by the synergic effect between EG and APP. Since the method used to evaluate the fire reaction behaviour does not allow to examine the fire performance such as number of ignitions, average combustion times and ignition times we can just affirm that the flammability is increased but not in what extent. The latent heat was reduced by approximately $70 \%$ due to the addition of $20 \%$ APP, while in our case the latent heat was reduced by $26 \%$ in case of adding 40\% APP to paraffin. Furthermore, the cycling stability was not studied for the composites containing $\mathrm{PCM} /$ holding matrix/flame retardant/high thermal conductivity particles.

Integration of PCM into building components such as walls, roofs, and floors can be broadly cover the possible application of the enhanced-PCM presented in this paper. The enhanced PCM could either be in the form of boards containing PCM, in the form of SSPCM slabs or mixed with concrete or bricks. Comparing to the literature review presented in Table 11, the main pros and cons shown by the three formulations proposed to be implemented are as follows: 
Pros:

- Thermal conductivity and fire reaction behaviour was improved at the same time.

- Cheaper than other composites using expensive supporting matrixes.

- Good compatibility between the PCM, high conductivity particle and flame retardant.

- Good thermal reliability after 1000 cycles.

- Latent heat was reduced in the same extent as other composites with the same structure (see Table 11).

\section{Cons:}

- Lower thermal conductivity than other systems just based on supporting material and high thermal conductivity particles [58,59].

- Lower latent heat than other systems just based on supporting material and high thermal conductivity particles [58,59].

However, the enhanced-PCM has shown potential to be used in building application further research is required to implement the material and overcome the cons listed above such as increasing the EG percentage, changing the PCM to one with higher latent heat or reducing the amount of flame retardant.

Table 11. Comparison of PCM composites based on building materials in the literature

\begin{tabular}{|c|c|c|c|c|c|c|c|c|c|}
\hline $\begin{array}{l}\text { PCM } \\
\text { (max } \\
\text { \%wt. } \\
\text { ) }\end{array}$ & $\begin{array}{l}\text { Support } \\
\text { ing } \\
\text { material } \\
\text { (\%wt.) }\end{array}$ & $\begin{array}{l}\text { Flame } \\
\text { retard } \\
\text { ant }\end{array}$ & $\begin{array}{l}\text { High } \\
\text { thermal } \\
\text { conducti } \\
\text { vity } \\
\text { particles }\end{array}$ & Method & $\begin{array}{l}\text { Late } \\
\text { nt } \\
\text { heat } \\
(\mathrm{kJ} / \mathrm{k} \\
\mathrm{g})\end{array}$ & $\begin{array}{l}\text { Thermal } \\
\text { conducti } \\
\text { vity } \\
(\mathrm{W} / \mathrm{m} \cdot \mathrm{K})\end{array}$ & $\begin{array}{l}\text { Fire } \\
\text { behavi } \\
\text { our }\end{array}$ & $\begin{array}{l}\text { Therm } \\
\text { al } \\
\text { reliabi } \\
\text { lity }\end{array}$ & $\begin{array}{l}\text { Re } \\
\text { f. }\end{array}$ \\
\hline $\begin{array}{l}\text { Capri } \\
\text { c } \\
\text { acid- } \\
\text { Palmit } \\
\text { ic acid }\end{array}$ & - & $\begin{array}{l}\text { Magnes } \\
\text { ium } \\
\text { hydroxi } \\
\text { de } \\
\text { (50\%wt. } \\
\text { ) }\end{array}$ & $\begin{array}{l}E G \\
(1 \% w t .)\end{array}$ & $\begin{array}{l}\text { Vacuum } \\
\text { impregna } \\
\text { tion }\end{array}$ & $\begin{array}{l}57 \\
(60 \% \\
\text { reduc } \\
\text { ed) }\end{array}$ & $\begin{array}{l}0.41 \\
(144 \%)\end{array}$ & $\begin{array}{l}\text { Improve } \\
\text { flammab } \\
\text { ility } \\
\text { propertie } \\
\text { s, self- } \\
\text { extinguis } \\
\text { hed } \\
\text { mechani } \\
\text { sm. }\end{array}$ & $\begin{array}{l}\text { Good } \\
\text { chemic } \\
\text { al } \\
\text { stability } \\
\text { after } \\
1000 \\
\text { cycles }\end{array}$ & $\begin{array}{l}\text { Thi } \\
\text { s } \\
\text { wo } \\
\text { rk }\end{array}$ \\
\hline $\begin{array}{l}\text { Capri } \\
\text { c } \\
\text { acid- } \\
\text { Myrist } \\
\text { ic acid }\end{array}$ & - & $\begin{array}{l}\text { Magnes } \\
\text { ium } \\
\text { hydroxi } \\
\text { de } \\
\text { (50\%wt. } \\
\text { ) }\end{array}$ & $\begin{array}{l}\text { EG } \\
\text { (1\%wt.) }\end{array}$ & $\begin{array}{l}\text { Vacuum } \\
\text { impregna } \\
\text { tion }\end{array}$ & $\begin{array}{l}64 \\
(52 \% \\
\text { reduc } \\
\text { ed) }\end{array}$ & $\begin{array}{l}0.32 \\
(91 \%)\end{array}$ & $\begin{array}{l}\text { Improve } \\
\text { flammab } \\
\text { ility } \\
\text { propertie } \\
\mathrm{s} \text {, self- } \\
\text { extinguis } \\
\text { hed } \\
\text { mechani }\end{array}$ & $\begin{array}{l}\text { Good } \\
\text { chemic } \\
\text { al } \\
\text { stability } \\
\text { after } \\
1000 \\
\text { cycles }\end{array}$ & $\begin{array}{l}\text { Thi } \\
\mathrm{s} \\
\text { wo } \\
\text { rk }\end{array}$ \\
\hline
\end{tabular}




\begin{tabular}{|c|c|c|c|c|c|c|c|c|c|}
\hline & & & & & & & $\mathrm{sm}$. & & \\
\hline $\begin{array}{l}\text { Paraff } \\
\text { in }\end{array}$ & - & $\begin{array}{l}\text { APP } \\
(40 \%)\end{array}$ & $\begin{array}{l}E G \\
\text { (1\%wt.) }\end{array}$ & $\begin{array}{l}\text { Vacuum } \\
\text { impregna } \\
\text { tion }\end{array}$ & $\begin{array}{l}83 \\
(26 \% \\
\text { reduc } \\
\text { ed) }\end{array}$ & $\begin{array}{l}0.26 \\
(71 \%)\end{array}$ & $\begin{array}{l}\text { Improve } \\
\text { flammab } \\
\text { ility } \\
\text { propertie } \\
\text { s by } \\
\text { synergic } \\
\text { effect } \\
\text { between } \\
\text { APP and } \\
\text { EG. }\end{array}$ & $\begin{array}{l}\text { Good } \\
\text { chemic } \\
\text { al } \\
\text { stability } \\
\text { after } \\
1000 \\
\text { cycles }\end{array}$ & $\begin{array}{l}\text { Thi } \\
\text { s } \\
\text { wo } \\
\text { rk }\end{array}$ \\
\hline $\begin{array}{l}\text { Capri } \\
\text { c acid }\end{array}$ & $\begin{array}{l}\text { Kaolin } \\
(17.5 \% \text { wt } \\
\text {.) }\end{array}$ & - & $\begin{array}{l}E G \\
\text { (5\%wt.) }\end{array}$ & $\begin{array}{l}\text { Vacuum } \\
\text { impregna } \\
\text { tion }\end{array}$ & $\begin{array}{l}27.23 \\
(9.8 \% \\
\text { reduc } \\
\text { ed) }\end{array}$ & $\begin{array}{l}0.23 \\
(35 \%)\end{array}$ & - & $\begin{array}{l}\text { Good } \\
\text { thermal } \\
\text { and } \\
\text { chemic } \\
\text { al } \\
\text { reliabilit } \\
\text { y after } \\
50 \\
\text { cycles. }\end{array}$ & $\begin{array}{l}{[58} \\
]\end{array}$ \\
\hline $\begin{array}{l}\text { Palmit } \\
\text { ic } \\
\text { acid- } \\
\text { Steari } \\
\text { c acid } \\
\text { (50\% } \\
\text { wt.) }\end{array}$ & $\begin{array}{l}\text { Bentonite } \\
\text { (45\%wt.) }\end{array}$ & - & $\begin{array}{l}\text { EG } \\
\text { (5\%wt.) }\end{array}$ & $\begin{array}{l}\text { Vacuum } \\
\text { impregna } \\
\text { tion }\end{array}$ & $\begin{array}{l}89.4 \\
(50 \% \\
\text { reduc } \\
\text { ed) }\end{array}$ & $\begin{array}{l}1.66 \\
(388 \%)\end{array}$ & - & $\begin{array}{l}\text { Good } \\
\text { thermal } \\
\text { and } \\
\text { chemic } \\
\text { al } \\
\text { reliabilit } \\
\text { y after } \\
50 \\
\text { cycles. }\end{array}$ & $\begin{array}{l}{[59} \\
]\end{array}$ \\
\hline $\begin{array}{l}\text { Capri } \\
\text { c } \\
\text { acid- } \\
\text { myrist } \\
\text { ic } \\
\text { acid- } \\
\text { palmit } \\
\text { ic acid }\end{array}$ & - & - & $\begin{array}{l}\text { EG } \\
\text { (7.4\%wt.) }\end{array}$ & $\begin{array}{l}\text { Vacuum } \\
\text { impregna } \\
\text { tion }\end{array}$ & $\begin{array}{l}153.5 \\
(6 \% \\
\text { reduc } \\
\text { ed) }\end{array}$ & $\begin{array}{l}2.51 \\
(900 \%)\end{array}$ & - & $\begin{array}{l}\text { Good } \\
\text { thermal } \\
\text { stability } \\
\text { after } \\
1200 \\
\text { cycles }\end{array}$ & $\begin{array}{l}{[46} \\
]\end{array}$ \\
\hline $\begin{array}{l}\text { Paraff } \\
\text { in } \\
(60 \%)\end{array}$ & $\begin{array}{l}\text { HDPE } \\
(20 \%)\end{array}$ & $\begin{array}{l}\text { APP } \\
(10 \%)\end{array}$ & $\begin{array}{l}E G \\
\text { (10wt.) }\end{array}$ & Extrusion & $\begin{array}{l}93.84 \\
(74 \% \\
\text { reduc } \\
\text { ed) }\end{array}$ & - & $\begin{array}{l}\text { Improve } \\
\text { flammab } \\
\text { ility } \\
\text { propertie } \\
\text { s by } \\
\text { synergic } \\
\text { effect } \\
\text { between } \\
\text { APP and } \\
\text { EG. }\end{array}$ & - & $\begin{array}{l}{[31} \\
]\end{array}$ \\
\hline $\begin{array}{l}\text { Paraff } \\
\text { in } \\
(60 \%)\end{array}$ & $\begin{array}{l}\text { HDPE } \\
(20 \%)\end{array}$ & $\begin{array}{l}\text { Zinc } \\
\text { borate } \\
(\text { ZB) } \\
(10 \%)\end{array}$ & $\begin{array}{l}\text { EG } \\
\text { (10\%wt.) }\end{array}$ & Extrusion & $\begin{array}{l}91.21 \\
(79 \% \\
\text { reduc } \\
\text { ed) }\end{array}$ & - & $\begin{array}{l}\text { Improve } \\
\text { flammab } \\
\text { ility } \\
\text { propertie } \\
\text { s by }\end{array}$ & - & $\begin{array}{l}{[31} \\
]\end{array}$ \\
\hline
\end{tabular}




\begin{tabular}{|c|c|c|c|c|c|c|c|c|c|}
\hline & & & & & & & $\begin{array}{l}\text { glassy } \\
\text { film } \\
\text { formatio } \\
n \text { of ZB. }\end{array}$ & & \\
\hline $\begin{array}{l}\text { Paraff } \\
\text { in } \\
(60 \%)\end{array}$ & $\begin{array}{l}\text { HDPE } \\
(15 \%)\end{array}$ & $\begin{array}{l}\text { APP } \\
(23 \%)\end{array}$ & $\begin{array}{l}\text { EG } \\
\text { (2\%wt.) }\end{array}$ & Extrusion & $\begin{array}{l}91.23 \\
(77 \% \\
\text { reduc } \\
\text { ed })\end{array}$ & - & $\begin{array}{l}\text { Improve } \\
\text { flammab } \\
\text { ility } \\
\text { propertie } \\
\text { s by } \\
\text { synergic } \\
\text { effect } \\
\text { between } \\
\text { APP and } \\
\text { EG. }\end{array}$ & - & $\begin{array}{l}\text { [57 } \\
\text { ] }\end{array}$ \\
\hline $\begin{array}{l}\text { Paraff } \\
\text { in } \\
(60 \%)\end{array}$ & $\begin{array}{l}\text { HDPE } \\
(15 \%)\end{array}$ & $\begin{array}{l}\text { APP } \\
(21 \%)\end{array}$ & $\begin{array}{l}E G \\
\text { (4\%wt.) }\end{array}$ & Extrusion & $\begin{array}{l}90.89 \\
(77 \% \\
\text { reduc } \\
\text { ed) }\end{array}$ & - & $\begin{array}{l}\text { Improve } \\
\text { flammab } \\
\text { ility } \\
\text { propertie } \\
\text { s by } \\
\text { synergic } \\
\text { effect } \\
\text { between } \\
\text { APP and } \\
\text { EG. }\end{array}$ & - & $\begin{array}{l}\text { [57 } \\
]\end{array}$ \\
\hline
\end{tabular}




\section{Conclusions}

To solve the major drawbacks of organic bulk-PCM enhanced PCM formulations were prepared by adding thermal conductivity particles and flame retardants.

The effective thermal conductivity of organic PCM was increased by using two different methods: adding $P G$ to melt bulk-PCM and impregnating PCM into EG. Thermal conductivity was measured with hot-wire technique.

The second stage was the addition of flame retardants to optimum PCM/graphite formulations to reduce their flammability. The fire performance of enhanced PCM was characterized by dripping test technique.

The impregnation of PCM into EG (1\% in wt.) showed the highest percentages of conductivity enhancement in all the cases. The maximum conductivity improvement was obtained with CAPA/EG by $256 \%$ in comparison to the reference PCM (in axial direction). The PCM/graphite composites are stable after 1000 thermal cycles.

\section{Acknowledgements}

The research leading to these results has received funding from the European Commission Seventh Framework Programme (FP/2007-2013) under grant agreement $\mathrm{n}^{\circ}$ PIRSES-GA-2013-610692 (INNOSTORAGE) and from the European Union's Horizon 2020 research and innovation program under grant agreement No 657466 (INPATH-TES). The authors would like to thank the Catalan Government for the quality accreditation given to their research groups GREA (2014 SGR 123), DIOPMA (2014 SGR 1543) and GICITED (2014 SGR 1298). The work partially funded by the Spanish government (ENE2015-64117-C5-1-R (MINECO/FEDER), ENE2015-64117-C5-2R(MINECO/FEDER), and ENE2015-64117-C5-3-R(MINECO/FEDER)). Dr. Alvaro de Gracia and Dr. Camila Barreneche would like to thank Ministerio de Economia y Competitividad de España for Grant Juan de la Cierva, FJCl-2014-19940 and FJCI2014-22886, respectively.

\section{References}

[1] D. Haillot, X. Py, V. Goetz, and M. Benabdelkarim, "Storage composites for the optimisation of solar water heating systems," Chem. Eng. Res. Des., vol. 86, no. 6, pp. 612-617, 2008.

[2] E. Oró, A. Gil, L. Miró, G. Peiró, S. Álvarez, and L. F. Cabeza, "Thermal energy storage implementation using phase change materials for solar cooling and refrigeration applications," Energy Procedia, vol. 30, pp. 947-956, 2012.

[3] T. G. Özbalta and S. Kartal, "Heat gain through Trombe wall using solar energy in a cold region of Turkey," vol. 5, no. 18, pp. 2768-2778, 2010.

[4] M. Ravikumar and D. P. Srinivasan, "Phase Change Material As a Thermal Energy Storage Material for Cooling of Building," J. Theor. Appl. Inf. Technol., vol. 14, 2008.

[5] S. D. Sharma and K. Sagara, "Latent heat storage materials and systems: A review," Int. J. Green Energy, vol. 2, pp. 1-56, 2005. 
[6] B. Zalba, J. M. Marín, L. F. Cabeza, and H. Mehling, Review on thermal energy storage with phase change: materials, heat transfer analysis and applications, vol. 23, no. 3. 2003.

[7] L. G. Gordeeva and Y. I. Aristov, "Composites 'salt inside porous matrix' for adsorption heat transformation: A current state-of-the-art and new trends," Int. J. Low-Carbon Technol., vol. 7, no. 4, pp. 288-302, 2012.

[8] A. Abhat, "Low temperature latent heat thermal energy storage: Heat storage materials," Solar Energy, vol. 30, no. 4. pp. 313-332, 1983.

[9] L. F. Cabeza, a. Castell, C. Barreneche, a. De Gracia, and a. I. Fernández, "Materials used as PCM in thermal energy storage in buildings: A review," Renew. Sustain. Energy Rev., vol. 15, no. 3, pp. 1675-1695, 2011.

[10] S. Jegadheeswaran and S. D. Pohekar, "Performance enhancement in latent heat thermal storage system: A review," Renew. Sustain. Energy Rev., vol. 13, no. 9, pp. 2225-2244, 2009.

[11] A. Mills, M. Farid, J. R. Selman, and S. Al-Hallaj, "Thermal conductivity enhancement of phase change materials using a graphite matrix," Appl. Therm. Eng., vol. 26, no. 14-15, pp. 1652-1661, 2006.

[12] L. F. Cabeza, H. Mehling, S. Hiebler, and F. Ziegler, "Heat transfer enhancement in water when used as PCM in thermal energy storage," Appl. Therm. Eng., vol. 22, no. 10, pp. 1141-1151, 2002.

[13] X. Py, R. Olives, and S. Mauran, "Paraffin/porous-graphite-matrix composite as a high and constant power thermal storage material," Int. J. Heat Mass Transf., vol. 44, no. 14, pp. 2727-2737, 2001.

[14] H. Mehling, S. Hiebler, F. Ziegler, and Z. a E. Bayern, "Latent heat storage using a PCM-graphite composite material."

[15] J. Chen, D. Yang, J. Jiang, A. Ma, and D. Song, "Research Progress of Phase Change Materials (PCMs) Embedded with Metal Foam (a Review)," Procedia Mater. Sci., vol. 4, pp. 369-374, 2014.

[16] S. Pincemin, R. Olives, X. Py, and M. Christ, "Highly conductive composites made of phase change materials and graphite for thermal storage," Sol. Energy Mater. Sol. Cells, vol. 92, no. 6, pp. 603-613, 2008.

[17] B. Tang, M. Qiu, and S. Zhang, "Thermal conductivity enhancement of PEG/SiO 2 composite PCM by in situ Cu doping," Sol. Energy Mater. Sol. Cells, vol. 105, pp. 242-248, 2012.

[18] O. Mesalhy, K. Lafdi, A. Elgafy, and K. Bowman, "Numerical study for enhancing the thermal conductivity of phase change material (PCM) storage using high thermal conductivity porous matrix," Energy Convers. Manag., vol. 46, no. 6, pp. 847-867, 2005.

[19] E. B. S. Mettawee and G. M. R. Assassa, "Thermal conductivity enhancement in a latent heat storage system,” Sol. Energy, vol. 81, no. 7, pp. 839-845, 2007. 
[20] H. Ettouney, I. Alatiqi, M. Al-Sahali, and K. Al-Hajirie, "Heat transfer enhancement in energy storage in spherical capsules filled with paraffin wax and metal beads," Energy Convers. Manag., vol. 47, no. 2, pp. 211-228, 2006.

[21] R. Velraj, R. V. Seeniraj, B. Hafner, C. Faber, and K. Schwarzer, "Heat Transfer Enhancement in a Latent Heat Storage System," Sol. Energy, vol. 65, no. 3, pp. 171-180, 1999.

[22] H. Babaei, P. Keblinski, and J. M. Khodadadi, "Improvement in thermal conductivity of paraffin by adding high aspect-ratio carbon-based nano-fillers," Phys. Lett. Sect. A Gen. At. Solid State Phys., vol. 377, no. 19-20, pp. 13581361, 2013.

[23] A. Elgafy and K. Lafdi, "Effect of carbon nanofiber additives on thermal behavior of phase change materials," Carbon N. Y., vol. 43, no. 15, pp. 3067-3074, 2005.

[24] P. Ji, H. Sun, Y. Zhong, and W. Feng, "Improvement of the thermal conductivity of a phase change material by the functionalized carbon nanotubes," Chem. Eng. Sci., vol. 81, pp. 140-145, 2012.

[25] J. Fukai, M. Kanou, Y. Kodama, and O. Miyatake, "Thermal conductivity enhancement of energy storage media using carbon fibers," Energy Convers. Manag., vol. 41, no. 14, pp. 1543-1556, 2000.

[26] M. Xiao, B. Feng, and K. C. Gong, "Preparation and performance of shape stabilized phase change thermal storage materials with high thermal conductivity," Energy Convers. Manag., vol. 43, no. 1, pp. 103-108, 2002.

[27] P. Zhang, Y. Hu, L. Song, J. Ni, W. Xing, and J. Wang, "Effect of expanded graphite on properties of high-density polyethylene/paraffin composite with intumescent flame retardant as a shape-stabilized phase change material," Sol. Energy Mater. Sol. Cells, vol. 94, no. 2, pp. 360-365, 2010.

[28] Y. Yuan, Y. Yuan, N. Zhang, Y. Du, and X. Cao, "Preparation and thermal characterization of capric-myristic-palmitic acid/expanded graphite composite as phase change material for energy storage," Mater. Lett., vol. 125, pp. 154157, 2014.

[29] S. Bocchini and G. Camino, "Halogen-containing flame retardants.," in Fire Retard. Polym. Mater. (2nd Ed.), 2010, pp. 75-105.

[30] S. D. Shaw, A. Blum, R. Weber, K. Kannan, D. Rich, D. Lucas, C. P. Koshland, D. Dobraca, S. Hanson, and L. S. Birnbaum, "Halogenated flame retardants: do the fire safety benefits justify the risks?," Rev. Environ. Health, vol. 25, no. 4, pp. 261-305, 2010.

[31] N. P. M. Q.Nguyen, "A review on fire protection for phase change materials in building applications," in From materials to structures: Advancement through Innovation, Chongmin S., 2012, pp. 561-566.

[32] T. D. Hapuarachchi and T. Peijs, "Aluminium trihydroxide in combination with ammonium polyphosphate as flame retardants for unsaturated polyester resin," Express Polym. Lett., vol. 3, no. 11, pp. 743-751, 2009. 
[33] L. Haurie, A. I. Fernández, J. I. Velasco, J. M. Chimenos, J.-M. Lopez Cuesta, and F. Espiell, "Synthetic hydromagnesite as flame retardant. Evaluation of the flame behaviour in a polyethylene matrix," Polym. Degrad. Stab., vol. 91, no. 5, pp. 989-994, 2006.

[34] J. H. Troitzsch, "Overview of Flame Retardants," Chim. Oggi, vol. 16, no. 1-2, pp. 18-24, 1998.

[35] J. Green, "A Review of Phosphorus- Containing Flame Retardants," J. Fire Sci., vol. 14, no. 5, pp. 353-366, 1992.

[36] F. Laoutid, L. Bonnaud, M. Alexandre, J. M. Lopez-Cuesta, and P. Dubois, "New prospects in flame retardant polymer materials: From fundamentals to nanocomposites," Mater. Sci. Eng. R Reports, vol. 63, no. 3, pp. 100-125, 2009.

[37] G. Song, S. Ma, G. Tang, Z. Yin, and X. Wang, "Preparation and characterization of flame retardant form-stable phase change materials composed by EPDM, paraffin and nano magnesium hydroxide," Energy, vol. 35, no. 5, pp. 2179-2183, 2010.

[38] S. V Levchik and E. D. Weil, "Flame retardancy of thermoplastic polyesters-a review of the recent literature," Polym. Int., vol. 54, no. 1, pp. 11-35, 2005.

[39] Y. Cai, Q. Wei, F. Huang, S. Lin, F. Chen, and W. Gao, "Thermal stability, latent heat and flame retardant properties of the thermal energy storage phase change materials based on paraffin/high density polyethylene composites," Renew. Energy, vol. 34, no. 10, pp. 2117-2123, 2009.

[40] G. Fang, H. Li, Z. Chen, and X. Liu, "Preparation and properties of palmitic acid/SiO2 composites with flame retardant as thermal energy storage materials," Sol. Energy Mater. Sol. Cells, vol. 95, no. 7, pp. 1875-1881, 2011.

[41] A. Palacios, A. de Gracia, L. Haurie, L. F. Cabeza, A. I. Fernández, and C. Barreneche., "Study of the thermal properties and the fire behaviour of new flame retardant-organic PCM in bulk form.," Submitt. to Constr. Mater. Build., 2016.

[42] Data sheet Rubitherm. Available at: http://www.rubitherm.de/english/pages/02a_latent_heat_pcms.htm (05/12/2015)

[43] D. D. L. Chung, "Review: Graphite," Journal of Materials Science, vol. 37, no. 8. pp. 1475-1489, 2002.

[44] D. Hanaor, M. Michelazzi, J. Chenu, C. Leonelli, and C. C. Sorrell, "The effects of firing conditions on the properties of electrophoretically deposited titanium dioxide films on graphite substrates," J. Eur. Ceram. Soc., vol. 31, no. 15, pp. 2877-2885, 2011.

[45] S. Desai and J. Njuguna, "Enhancement of thermal conductivity of materials using different forms of natural graphite," vol. 40, no. Nanostruc, pp. 1-22, 2012.

[46] X. Yang, Y. Yuan, N. Zhang, X. Cao, and C. Liu, "Preparation and properties of myristic-palmitic-stearic acid/expanded graphite composites as phase change materials for energy storage," Sol. Energy, vol. 99, pp. 259-266, 2014. 
[47] N. Zhang, Y. Yuan, X. Wang, X. Cao, X. Yang, and S. Hu, "Preparation and characterization of lauric-myristic-palmitic acid ternary eutectic mixtures/expanded graphite composite phase change material for thermal energy storage," Chem. Eng. J., vol. 231, pp. 214-219, 2013.

[48] A. Sari and A. Karaipekli, "Thermal conductivity and latent heat thermal energy storage characteristics of paraffin/expanded graphite composite as phase change material," Appl. Therm. Eng., vol. 27, no. 8-9, pp. 1271-1277, 2007.

[49] L. Xia, P. Zhang, and R. Z. Wang, "Preparation and thermal characterization of expanded graphite/paraffin composite phase change material," Carbon N. Y., vol. 48, no. 9, pp. 2538-2548, 2010.

[50] W. L. Cheng, R. M. Zhang, K. Xie, N. Liu, and J. Wang, "Heat conduction enhanced shape-stabilized paraffin/HDPE composite PCMs by graphite addition: Preparation and thermal properties," Sol. Energy Mater. Sol. Cells, vol. 94, no. 10, pp. 1636-1642, 2010.

[51] M. Li, "A nano-graphite/paraffin phase change material with high thermal conductivity," Appl. Energy, vol. 106, pp. 25-30, 2013.

[52] Y. Zhong, M. Zhou, F. Huang, T. Lin, and D. Wan, "Effect of graphene aerogel on thermal behavior of phase change materials for thermal management," Sol. Energy Mater. Sol. Cells, vol. 113, pp. 195-200, 2013.

[53] S. Kim and L. T. Drzal, "High latent heat storage and high thermal conductive phase change materials using exfoliated graphite nanoplatelets," Sol. Energy Mater. Sol. Cells, vol. 93, no. 1, pp. 136-142, 2009.

[54] B. Tryba, a. W. Morawski, and K. Kałucki, "Trace analyses of gaseous products formed during heat treatment of high stage H2SO4-GICs and expanded graphite," J. Phys. Chem. Solids, vol. 65, no. 2-3, pp. 165-169, 2004.

[55] A. S. Mujumdar, Book Review: Handbook of Industrial Drying, Third Edition, vol. 25, no. 6. 2006.

[56] C. Barreneche, A. Solé, L. Miró, I. Martorell, A. I. Fernández, and L. F. Cabeza, "Study on differential scanning calorimetry analysis with two operation modes and organic and inorganic phase change material (PCM)," Thermochim. Acta, vol. 553, pp. 23-26, 2013.

[57] W. Lin, J. Yuan, and B. Sundén, "Review on graphite foam as thermal material for heat exchangers," pp. 748-755.

[58] Z. Fan, P. Tsakiropoulos, and A. P. Miodownik, "A generalized law of mixtures," J. Mater. Sci., vol. 29, no. 1, pp. 141-150, 1994.

[59] G. Ferrer, A. Solé, C. Barreneche, I. Martorell, L.F. Cabeza. Review on the methodology used in thermal stability characterization of phase change materials. Renew. Sustain. Energy Rev., vol. 50, 665-685. 